\title{
PARTICIPATION IN MULTILATERAL TREATIES*
}

\section{Editorial introduction}

This section records the participation of Asian states in open, multilateral law-making treaties which mostly aim at world-wide adherence. Volume 6 of the Yearbook included the cumulative and updated data contained in Volumes 1 to 5 . In the present and following Volumes these data will be updated. This will be done by presenting the new data preceded by "Continued from Vol. 6". In case no new data are available, the title of the treaty will be listed with a mere reference to the data in Volume 6.

Due to the conversion of the manuscript from WordPerfect into Word, unfortunately a number of errors have slipped into the tables presented in Volume 6. These errors are corrected in the present Volume by inclusion of the correct data and addition of the words "Corrected [and updated] from Vol. 6". If the table concerned in Volume 6 contained more than three errors, the whole table is reproduced including the corrections. In that case the table is preceded by the words "Reproduced from Vol. 6, as corrected [and updated]".

For the purpose of this section states broadly situated west of Iran, north of Mongolia, east of Papua New Guinea and south of Indonesia will not be covered. The Editors wish to express their gratitude to all those international organisations that have so kindly responded to our request by making available information on the status of various categories of treaties.

Note:

- Where no other reference to specific sources is made, data are derived from Multilateral Treaties deposited with the Secretary-General - Status as at 31 December 1997 (ST/LEG/SER.E/16).

- No indication is given of reservations and declarations made.

- Sig. = signature; Cons. = consent to be bound.

\section{TABLE OF HEADINGS}

Antarctica

Commercial arbitration

Cultural matters

Cultural property

Development matters

Dispute settlement

Environment, fauna and flora

Family matters

Finance
Human rights, including women and children

Humanitarian law in armed conflict

Intellectual property

International crimes

International representation

International trade

Health

Judicial and administrative cooperation

\footnotetext{
" Compiled by Karin Arts, Assistant Editor.
}

Asian Yearbook of International Law, Volume 7 (Ko Swan Sik et al., eds.

${ }^{\circ}$ Kluwer Law International; printed in the Netherlands), pp. 321-342 
Labour

Narcotic drugs

Nationality and statelessness

Nuclear material

Outer space

Privileges and immunities

Refugees
Road traffic and transport

Sea

Sea traffic and transport

Social matters

Telecommunications

Treaties

Weapons

\section{ANTARCTICA}

Antarctic Treaty, Washington, 1959: see Vol. 6 p. 234.

\section{COMMERCIAL ARBITRATION}

Convention on the Recognition and Enforcement of Foreign Arbitral Awards, 1958 (Reproduced from Vol. 6 p. 234, as corrected and updated)

\begin{tabular}{|c|c|c|c|c|c|}
\hline State & Sig. & Cons. & State & Sig. & Cons. \\
\hline Bangladesh & & 6 May 92 & Malaysia & & 5 Nov 85 \\
\hline Brunei & & $25 \mathrm{Jul} 96$ & Mongolia & & 24 Oct 94 \\
\hline Cambodia & & $5 \operatorname{Jan} 60$ & Pakistan & & $30 \mathrm{Dec} 58$ \\
\hline China & & 22 Jan 87 & Philippines & 10 Jun 58 & $6 \mathrm{Jul} 67$ \\
\hline India & 10 Jun 58 & $13 \mathrm{Jul} 60$ & Singapore & & 21 Aug 86 \\
\hline Indonesia & & 7 Oct 81 & Sri Lanka & $30 \operatorname{Dec} 58$ & 9 Apr 62 \\
\hline Japan & & 20 Jun 61 & Thailand & & 21 Dec 59 \\
\hline Kazakhstan & & 20 Nov 95 & Uzbekistan & & 7 Feb 96 \\
\hline Korea (Rep.) & & 8 Feb 73 & Vietnam & & 12 Sep 95 \\
\hline Kyrgyzstan & & $18 \operatorname{Dec} 96$ & & & \\
\hline
\end{tabular}

\section{CULTURAL MATTERS}

Convention concerning the International Exchange of Publications, 1958: see Vol. 6 p. 235.

Convention concerning the International Exchange of Official Publications and Government Documents between States, 1958: see Vol. 6 p. 235.

International Agreement for the Establishment of the University for Peace, New York, 1980: see Vol. 6 p. 235.

Regional Convention on the Recognition of Studies, Diploma's and Degrees in Higher Education in Asia and the Pacific, Bangkok, 1983: see Vol. 6 p. 235.

Agreement for Facilitating the International Circulation of Visual and Auditory Materials of an Educational, Scientific and Cultural Character, Beirut, 1948

(Corrected from Vol. 6 p. 234) 
State

Sig. Cons.

Cambodia

$20 \mathrm{Feb} 52$

Agreement on the Importation of Educational, Scientific and Cultural Materials, Florence, 1950

(Reproduced from Vol. 6 p. 234, as corrected and updated)

\begin{tabular}{lll|lll} 
State & Sig. & Cons. & State & Sig. & Cons. \\
Afghanistan & 8 Oct 51 & 19 Mar 58 & Philippines & 22 Nov 50 & 30 Aug 52 \\
Cambodia & & 5 Nov 51 & Singapore & & 11 Jul 69 \\
Iran & 31 Dec 49 & 30 Dec 59 & Sri Lanka & & 8 Jan 52 \\
Pakistan & 9 May 51 & 7 Jan 52 & Thailand & 22 Nov 50 & 18 Jan 51
\end{tabular}

\section{CULTURAL PROPERTY}

Protocol for the Protection of Cultural Property in the Event of Armed Conflict, 1954: see Vol. 6 p. 236.

Convention on the Means of Prohibiting and Preventing the Illicit Import, Export and Transfer of Ownership of Cultural Property, 1970: see Vol. 6 p. 236.

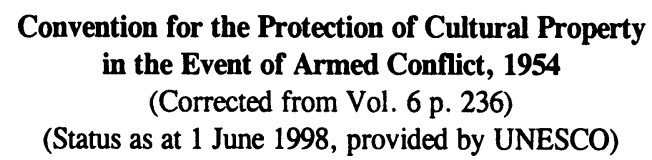

State Cons. (deposit)

Uzbekistan 21 Feb 96
Convention concerning the Protection of the World Cultural and Natural Heritage, 1972
(Continued from Vol. 6 p. 237)
(Status as at 1 June 1998, provided by UNESCO)

State

Cons. (deposit)

Papua New Guinea

$28 \mathrm{Jul} 97$

\section{DEVELOPMENT MATTERS}

Charter of the Asian and Pacific Development Centre, 1982

(Reproduced from Vol. 6 p. 237, as corrected and updated)

$\begin{array}{llllll}\text { State } & \text { Sig. } & \text { Cons. } & \text { State } & \text { Sig. } & \text { Cons. } \\ \text { Bangladesh } & & 9 \text { Sep 82 } & \text { China } & & 18 \text { Feb 83 } \\ \text { Brunei } & \text { 14 Feb 85 } & \text { India } & & 25 \text { Apr 83 }\end{array}$




\begin{tabular}{lll|lll} 
State & Sig. & Cons. & State & Sig. & Cons. \\
Indonesia & & 7 Jan 83 & Nepal & & 25 Apr 83 \\
Japan & 9 Sep 82 & Pakistan & & 9 Sep 82 \\
$\begin{array}{l}\text { Korea (Rep.) } \\
\text { Laos }\end{array}$ & 9 Sep 82 & Philippines & & 15 Dec 82 \\
$\begin{array}{l}\text { Macau (ass. member) } \\
\text { Malaysia }\end{array}$ & 3 Jun 82 & Sri Lanka & 9 Sep 82 & \\
Maldives & Thailand & & 27 Jun 83 \\
9 Sep 82 & Vietnam & & 9 Sep 82 \\
\end{tabular}

Agreement to Establish the South Centre, 1994

(Continued from Vol. 6 p. 237)

$\begin{array}{lll}\text { State } & \text { Sig. } & \text { Cons. } \\ \text { Iran } & 30 \text { Sep } 94 & 11 \text { Sep } 97\end{array}$

\section{DISPUTE SETTLEMENT}

Declarations recognizing as compulsory the jurisdiction of the International Court of Justice under Article 36, paragraph 2, of the Statute of the Court, see Vol. 6 p. 238. Convention on the Settlement of Investment Disputes between States and Nationals of Other States, 1965: see Vol. 6 p. 238.

\section{ENVIRONMENT, FAUNA AND FLORA}

International Convention for the Prevention of Pollution of the Sea by Oil, as amended, 1954: see Vol. 6 p. 238.

International Convention on Civil Liability for Oil Pollution Damage, 1969: see Vol. 6 p. 239.

International Convention on the Establishment of an International Fund for Compensation for Oil Pollution Damage, 1971: see Vol. 6 p. 240.

Protocol to the International Convention on Civil Liability for Oil Pollution Damage, 1976: see Vol. 6 p. 239.

Protocol to amend the 1971 Convention on Wetlands of International Importance especially as Waterfowl Habitat, 1982: see Vol. 6 p. 240.

Amendments to Articles 6 and 7 of the 1971 Convention on Wetlands of International Importance especially as Waterfowl Habitat, 1987: see Vol. 6 p. 240.

Convention for the Protection of the Ozone Layer, 1985: see Vol. 6 p. 241.

Protocol on Substances that Deplete the Ozone Layer, 1987: see Vol. 6 p. 241.

\section{International Convention Relating to Intervention on the High Seas in Cases of} Oil Pollution Casualties, 1969

(Continued from Vol. 6 p. 238)

(Status as included in IMO doc. J/6783, as at 31 December 1997) 
State

Cons. (deposit) E.i.f.

Iran

25 Jul 97

23 Oct 97

Convention on Wetlands of International Importance especially

as Waterfowl Habitat, 1971

(Continued from Vol. 6 p. 240)

(Status as at 1 June 1998, provided by UNESCO)

State

Cons. (deposit)

Mongolia

8 Dec 97

Convention on the Prevention of Marine Pollution by Dumping of Wastes and Other Matter, 1972, as amended

(Continued from Vol. 6 p. 240)

(Status as included in IMO doc. J/6783, as at 31 December 1997)

State

Cons. (deposit) E.i.f.

Iran

13 Jan 97

12 Feb 97

Protocol Relating to Intervention on the High Seas in Cases of Pollution

by Substances Other Than Oil, 1973

(Continued from Vol. 6 p. 239)

(Status as included in IMO doc. J/6783, as at 31 December 1997)

State

Cons. (deposit) E.i.f.

Iran

$25 \mathrm{Jul} 97$

23 Oct 97

Protocol Relating to the 1973 International Convention for the Prevention of Pollution from Ships, as amended, 1978

(Continued from Vol. 6 p. 241)

(Status as included in IMO doc. J/6783, as at 31 December 1997)

State

Cons. (deposit) Excepted

annexes

Korea (Rep.)

annexes III and V: 28 Feb 96

Malaysia $\quad 31$ Jan 97

Sri Lanka $\quad 24$ Jun 97

III, IV

Convention on the Control of Transboundary Movements of Hazardous Wastes and Their Disposal, 1989

(Corrected and Updated from Vol. 6 p. 242)

State

Sig.

Cons.

State

Sig.

Cons.

Kyrgyzstan

13 Aug 96

Mongolia

15 Apr 97

Thailand

$22 \operatorname{Mar} 90$

24 Nov 97 
Amendment to the Montreal Protocol, 1990

(Continued from Vol. 6 p. 242)

State

Cons.

Iran

4 Aug 97

Amendment to the Montreal Protocol, 1992

(Corrected and Updated from Vol. 6 p. 242)

State

Iran

Sri Lanka

Cons.

State

Cons.

4 Aug 97

7 Jul 97

Thailand

1 Dec 95

Framework Convention on Climate Change, 1992

(Continued from Vol. 6 p. 243)

State

Sig.

Cons.

Singapore

13 Jun 92

29 May 97

Convention on Biological Diversity, 1992

(Continued from Vol. 6 p. 243)

State

Sig.

Cons.

Tajikistan

29 Oct 97

Protocol to amend the 1969 International Convention on Civil Liability for Oil Pollution Damage, 1992

(Continued from Vol. 6 p. 239)

(Status as included in IMO doc. J/6783, as at 31 December 1997)

\begin{tabular}{|c|c|c|c|c|c|}
\hline State & Cons. (deposit) & E.i.f. & State & Cons. (deposit) & E.i.f. \\
\hline & 24 Aug 94 & 30 May 96 & Philippines & $7 \mathrm{Jul} 97$ & $7 \mathrm{Jul} 98$ \\
\hline orea (Rep.) & 7 Mar 97 & 16 May 98 & Singapore & 18 Sep 97 & $18 \operatorname{Sep} 98$ \\
\hline
\end{tabular}

\section{FAMILY MATTERS}

Convention on the Recovery Abroad of Maintenance, 1956: see Vol. 6 p. 243.

Convention on the Law Applicable to Maintenance Obligations Towards Children, 1956: see Vol. 6 p. 244.

Convention on the Law Applicable to Maintenance Obligations, 1973: see Vol. 6 p. 244. Convention on Protection of Children and Co-operation in respect of Intercountry Adoption, 1993: see Vol. 6 p. 244 
Convention on the Conflicts of Law Relating to the Form of

Testamentary Dispositions, 1961

(Corrected from Vol. 6 p. 244)

State

Cons.

Hong Kong

23 Aug 68

Convention on Consent to Marriage, Minimum Age for Marriage and Registration of Marriages, 1962

(Continued from Vol. 6 p. 244)

State Cons.

Kyrgyzstan 10 Feb 97

\section{FINANCE}

Convention Establishing the Multilateral Investment Guarantee Agency, 1988

((Reproduced from Vol. 6 p. 245, as corrected and updated) )

(Status as at 31 December 1997, provided by the World Bank)

\begin{tabular}{|c|c|c|c|c|c|}
\hline State & Sig. & Cons. & State & Sig. & Cons. \\
\hline Bangladesh & 13 Mar 87 & 13 Mar 87 & Pakistan & $7 \mathrm{Jul} 86$ & 1 Dec 86 \\
\hline Cambodia & 1 Oct 93 & & Papua & & \\
\hline China & 23 Apr 88 & 30 Apr 88 & New Guinea & 9 May 90 & 29 Oct 90 \\
\hline India & 13 Apr 92 & $20 \operatorname{Sep} 93$ & Philippines & 15 Sep 86 & 22 Nov 93 \\
\hline Indonesia & 26 Jun 86 & $26 \operatorname{Sep} 86$ & Singapore & 3 Jun 97 & 20 Jun 97 \\
\hline Japan & $12 \operatorname{Sep} 86$ & 5 Jun 87 & Sri Lanka & 3 Oct 86 & 27 May 88 \\
\hline Kazakhstan & $23 \mathrm{Jul} 92$ & 18 Sep 92 & Tadjikistan & 4 Jun 93 & $26 \mathrm{Jul} 93$ \\
\hline Korea (Rep.) & 11 Oct 85 & 24 Nov 87 & Thailand & 3 Oct 96 & \\
\hline Kyrgyzstan & $28 \operatorname{Sep} 92$ & 21 Sep 93 & Turkmenistan & 26 Sep 92 & 26 Sep 92 \\
\hline Malaysia & 2 Jul 91 & 2 Aug 91 & Uzbekistan & 24 Sep 92 & $24 \operatorname{Sep} 92$ \\
\hline Mongolia & 14 Jun 91 & $6 \mathrm{Jan} 92$ & Vietnam & 27 Sep 93 & 4 Apr 94 \\
\hline Nepal & 23 Sep 92 & 23 Sep 93 & & & \\
\hline
\end{tabular}

Agreement Establishing the Asian Development Bank, 1965

(Corrected and updated from Vol. 6 p. 245)

\begin{tabular}{lll|lll} 
State & Sig. & Cons. & State & Sig. & Cons. \\
China & & 10 Mar 86 & Indonesia & & 24 Nov 66 \\
Hong Kong & 27 Mar 69 & Uzbekistan & & 31 Aug 95
\end{tabular}

\section{HEALTH}

Protocol Concerning the Office International d'Hygiène Publique, 1946: see Vol. 6 p. 245. 


\section{HUMAN RIGHTS, INCLUDING WOMEN AND CHILDREN}

International Convention against Apartheid in Sports, 1985: see Vol. 6 p. 248.

International Convention on the Protection of the Rights of All Migrant Workers and Members of Their Families, 1990, see Vol. 6 p. 249.

Amendment to article 8 of the International Convention on the Elimination of All Forms of Racial Discrimination, 1992: see Vol. 6 p. 247.

Convention on the Political Rights of Women, 1953

(Reproduced from Vol. 6 p. 246, as corrected and updated)

\begin{tabular}{lll|lll} 
State & Sig. & Cons. & State & Sig. & Cons. \\
Afghanistan & & 16 Nov 66 & Myanmar & 14 Sep 54 & \\
India & 29 Apr 53 & 1 Nov 61 & Nepal & & 26 Apr 66 \\
Indonesia & 31 Mar 53 & 16 Dec 58 & Pakistan & 18 May 54 & 7 Dec 54 \\
Japan & 1 Apr 55 & 13 Jul 55 & Papua & & \\
Korea (Rep.) & & 23 Jun 59 & New Guinea & & 27 Jan 82 \\
Kyrgyzstan & & 10 Feb 97 & Philippines & 23 Sep 53 & 12 Sep 57 \\
Laos & & 28 Jan 69 & Thailand & 5 Mar 54 & 30 Nov 54 \\
Mongolia & & 18 Aug 65 & Uzbekistan & & 29 Sep 97
\end{tabular}

Convention on the Nationality of Married Women, 1957

(Continued from Vol. 6 p. 246)

State

Kyrgyzstan Sig.

Cons.

10 Feb 97

Convention against Discrimination in Education, 1960

(Continued from Vol. 6 p. 246)

(Status as at 1 June 1998, provided by UNESCO)

State Sig. Cons.

Uzbekistan

8 Dec 97

International Covenant on Economic, Social and Cultural Rights, 1966

(Continued from Vol. 6 p. 246)

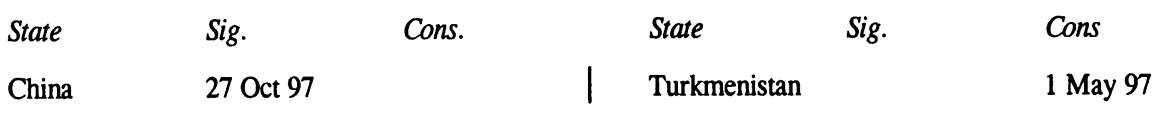

\section{International Covenant on Civil and Political Rights, 1966}

(Corrected and updated from Vol. 6 p. 246)

\begin{tabular}{lll|lll} 
State & Sig. & Cons. & State & Sig. & Cons. \\
Iran & 4 Apr 68 & 24 Jun 75 & Turkmenistan & & 1 May 97 \\
Mongolia & 5 Jun 68 & 18 Nov 74 & &
\end{tabular}


Optional Protocol to the International Covenant on Civil and Political Rights, 1966

(Continued from Vol. 6 p. 247)

$\begin{array}{llllll}\text { State } & \text { Sig. } & \text { Cons. } & \text { State } & \text { Sig. } & \text { Cons. } \\ \text { Sri Lanka } & & 3 \text { Oct } 97 & \text { Turkmenistan } & & 1 \text { May } 97\end{array}$

International Convention on the Elimination of All Forms of Racial Discrimination, 1966

(Continued from Vol. 6 p. 247)

State Sig. Cons.

Kyrgyzstan $\quad 5$ Sep 97

Convention on the Elimination of All Forms of Discrimination against Women, 1979

(Corrected and updated from Vol. 6 p. 247)

\begin{tabular}{|c|c|c|c|c|}
\hline State & Sig. & Cons. & State & Cons. \\
\hline Kyrgyzstan & & 10 Feb 97 & Pakistan & $12 \operatorname{Mar} 96$ \\
\hline Malaysia & & $5 \mathrm{Jul} 95$ & Papua New Guinea & $12 \operatorname{Jan} 95$ \\
\hline Maldives & & $1 \mathrm{Jul} 93$ & Turkmenistan & 1 May 97 \\
\hline Myanmar & & 22 Jul 97 & & \\
\hline
\end{tabular}

\section{Convention against Torture and Other Cruel, Inhuman or Degrading Treatment or Punishment, 1984}

(Continued from Vol. 6 p. 248)

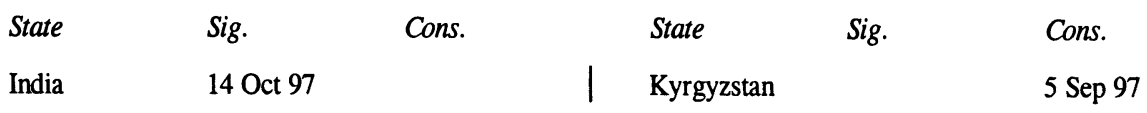

Convention on the Rights of the Child, 1989

(Corrected from Vol. 6 p. 248)

$\begin{array}{llllll}\text { State } & \text { Sig. } & \text { Cons. } & \text { State } & \text { Sig. } & \text { Cons. } \\ \text { Tajikistan } & & 26 \text { Oct 93 } & \text { Turkmenistan } & & 20 \text { Sep } 93 \\ \text { Thailand } & 27 \text { Mar 92 } & & \end{array}$

\section{HUMANITARIAN LAW IN ARMED CONFLICT}

International Conventions for the Protection of Victims of War, I-IV, 1949: see Vol. $6 \mathrm{p}$. 249.

Protocol II Additional to the Geneva Conventions of 12 August 1949, and Relating to the Protection of Victims of Non-International Armed Conflicts, 1977: see Vol. 6 p. 250 . 
Protocol I Additional to the Geneva Conventions of 12 August 1949, and Relating to the Protection of Victims of International Armed Conflicts, 1977

(Corrected from Vol. 6 p. 249)

$\begin{array}{lll}\text { State } & \text { Sig. } & \text { Cons. } \\ \text { Laos } & & 18 \text { Nov } 80\end{array}$

\section{INTELLECTUAL PROPERTY}

Convention for the Protection of Industrial Property, 1883 (most recently revised Stockholm, 1967 and amended 1979): see Vol. 6 p. 250.

Convention for the Protection of Literary and Artistic Works, 1886 (most recently revised Paris, 1971 and amended 1979): see Vol. 6 p. 250.

Universal Copyright Convention, 1952: see Vol. 6 p. 251.

Protocols 1, 2 and 3 annexed to the Universal Copyright Convention, 1952: see Vol. 6 p. 251.

Convention Establishing the World Intellectual Property Organization, 1967: see Vol. 6 p. 252.

Convention for the Protection of Producers of Phonograms against Unauthorized Duplication of their Phonograms, 1971: see Vol. 6 p. 252.

Multilateral Convention for the Avoidance of Double Taxation of Copyright Royalties, 1979: see Vol. 6 p. 252.

\section{INTERNATIONAL CRIMES}

Convention on Offences and Certain Other Acts Committed on Board Aircraft, 1963: see Vol. 6 p. 254.

Convention on the Non-Applicability of Statutory Limitations to War Crimes and Crimes Against Humanity, 1968: see Vol. 6 p. 254.

Convention for the Suppression of Unlawful Seizure of Aircraft, 1970: see Vol. 6 p. 254.

Convention for the Suppression of Unlawful Acts Against the Safety of Civil Aviation, 1971: see Vol. 6 p. 255.

International Convention Against the Taking of Hostages, 1979: see Vol. 6 p. 255.

Convention for the Suppression of Unlawful Acts Against the Safety of Maritime Navigation, 1988, see Vol. 6 p. 256.

Protocol for the Suppression of Unlawful Acts Against the Safety of Fixed Platforms Located on the Continental Shelf, 1988, see Vol. 6 p. 256.

Protocol for the Suppression of Unlawful Acts of Violence at Airports Serving International Civil Aviation, Supplementary to the Convention for the Suppression of Unlawful Acts Against the Safety of Civil Aviation, 1988, see Vol. 6 p. 256.

International Convention against the Recruitment, Use, Financing and Training of Mercenaries, 1989: see Vol. 6 p. 256. 


\section{Slavery Convention, 1926 as amended in 1953}

(Continued from Vol. 6 p. 253)

$\begin{array}{llllll}\text { State } & \text { Sig. } & \text { Cons. } & \text { State } & \text { Sig. } & \text { Cons. } \\ \text { Kyrgyzstan } & & 5 \text { Sep } 97 & \text { Turkmenistan } & & 1 \text { May } 1997\end{array}$

Convention on the Prevention and Punishment of the Crime of Genocide, 1948

(Continued from Vol. 6 p. 253)

$\begin{array}{lll}\text { State } & \text { Sig. } & \text { Cons. } \\ \text { Kyrgyzstan } & & 5 \text { Sep } 97\end{array}$

Supplementary Convention on the Abolition of Slavery, the Slave Trade, and Institutions and Practices Similar to Slavery, 1956

(Continued from Vol. 6 p. 253)

$\begin{array}{llllll}\text { State } & \text { Sig. } & \text { Cons. } & \text { State } & \text { Sig. } & \text { Cons. } \\ \text { Kyrgyzstan } & & 5 \text { Sep } 97 & \text { Turkmenistan } & & 1 \text { May } 97\end{array}$
International Convention on the Suppression and Punishment
of the Crime of Apartheid, 1973
(Continued from Vol. 6 p. 255)

$\begin{array}{lll}\text { State } & \text { Sig. } & \text { Cons. } \\ \text { Kyrgyzstan } & & 5 \text { Sep } 97\end{array}$

Convention on the Prevention and Punishment of Crimes Against Internationally Protected Persons Including Diplomatic Agents, 1973

(Continued from Vol. 6 p. 255)

State Sig. Cons.

Brunei 13 Nov 97

Convention on the Marking of Plastic Explosives for the Purpose of Detection, 1991

(Continued from Vol. 6 p. 256)

(Status as included in IMO doc. J/6783, as at 31 December 1997)

State Sig. Cons.

Japan 26 Sep 97 


\section{INTERNATIONAL REPRESENTATION \\ (see also: Privileges and Immunities)}

Vienna Convention on the Representation of States in their relations with International Organizations of a Universal Character, 1975: see Vol. 6 p. 257.

\section{INTERNATIONAL TRADE}

Convention on Transit Trade of Land-locked States, 1965: see Vol. 6 p. 257.

Convention on the Limitation Period in the International Sale of Goods, 1974: see Vol. 6 p. 257.

UN Convention on the Liability of Operators of Transport Terminals in International Trade, 1991: see Vol. 6 p. 257.

UN Convention on Contracts for the International Sale of Goods, 1980

(Continued from Vol. 6 p. 257)

State Sig. Cons.

Mongolia

31 Dec 97

\section{JUDICIAL AND ADMINISTRATIVE COOPERATION}

Convention Relating to Civil Procedure, 1954: see Vol. 6 p. 258.

Convention Abolishing the Requirement of Legalisation for Foreign Public Documents, 1961

(Corrected from Vol. 6 p. 258)

(Status as provided by the Permanent Bureau of the Hague Conference on Private International law)

State Sig. Cons.

Hong Kong 25 Apr 65

Convention on the Service Abroad of Judicial and Extrajudicial Documents in

Civil or Commercial Matters, 1965

(Corrected from Vol. 6 p. 258)

(Status as provided by the Permanent Bureau of the Hague Conference on Private International law)

State Sig. Cons.

Hong Kong 19 Jul 70

Convention on the Taking of Evidence Abroad in Civil or Commercial Matters, 1970

(Corrected from Vol. 6 p. 258).

(Status as provided by the Permanent Bureau of the Hague Conference on Private International law) 


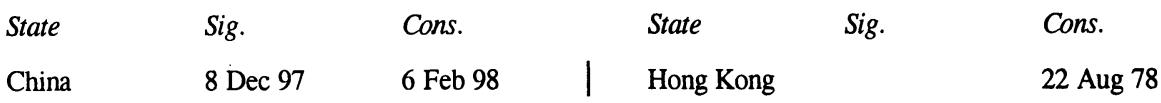

\section{LABOUR}

Forced Labour Convention, 1930 (ILO Conv. 29)

(Corrected and updated from Vol. 6 p. 259)

State

Turkmenistan

Ratif. registered

State

15 May 97

Uzbekistan

\section{Freedom of Association and Protection of the Right to Organise Convention, 1948 (ILO Conv. 87)}

(Continued from Vol. 6 p. 259)
State

Turkmenistan
Ratif. registered

15 May 97
Ratif. registered

$13 \mathrm{Jul} 92$

Right to Organise and Collective Bargaining Convention, 1949 (ILO Conv. 98)

(Corrected and updated from Vol. 6 p. 259)

State

Turkmenistan
Ratif. registered

15 May 97
State

Uzbekistan
Ratif. registered

13 Jul 92

Equal Remuneration Convention, 1951 (ILO Conv. 100)

(Continued from Vol. 6 p. 259)

\begin{tabular}{ll|l} 
State & Ratif. registered & State \\
Korea (Rep.) & 8 Dec 97 & Uzbekistan \\
Malaysia & 9 Sep 97 & Vietnam \\
Turkmenistan & 15 May 97 &
\end{tabular}

Ratif. registered

13 Jul 92

7 Oct 97

Abolition of Forced Labour Convention, 1957 (ILO Conv. 105)

(Continued from Vol. 6 p. 260)

$\begin{array}{llllc}\text { State } & \text { Ratif. registered } & \text { State } & \text { Ratif. registered } \\ \text { Turkmenistan } & 15 \text { May } 97 & \text { Uzbekistan } & 15 \mathrm{Dec} 97\end{array}$

Discrimination (Employment and Occupation) Convention, 1958 (ILO Conv. 111) (Corrected and updated from Vol. 6 p. 260)

\begin{tabular}{ll|lc} 
State & Ratif. registered & State & Ratif. registered \\
Turkmenistan & 15 May 97 & Vietnam & 7 Oct 97 \\
Uzbekistan & 13 Jul 92 & &
\end{tabular}




\section{Employment Policy Convention, 1964 (ILO Conv. 122)}

(Corrected and updated from Vol. 6 p. 260)

State

Ratif. registered

China

17 Dec 97

\section{NARCOTIC DRUGS}

Agreement Concerning the Suppression of the Manufacture of, Internal Trade in, and Use of, Prepared Opium and amended by Protocol, 1925, amended 1946: see Vol. 6 p. 261.

Agreement Concerning the Suppression of Opium Smoking, 1931, amended by Protocol, 1946: see Vol. 6 p. 261.

Protocol Amending the Agreements, Conventions and Protocols on Narcotic Drugs, concluded at The Hague on 23 January 1912, at Geneva on 11 February 1925 and 19 February 1925 and 13 July 1931, at Bangkok on 27 November 1931 and at Geneva on 26 June 1936, 1946: see Vol. 6 p. 261.

Protocol bringing under International Control Drugs outside the Scope of the Convention of 1931, as amended by the protocol of 1946: see Vol. 6 p. 262.

Convention for the Suppression of the Illicit Traffic in Dangerous Drugs, 1936, amended 1946: see Vol. 6 p. 262.

Protocol for Limiting and Regulating the Cultivation of the Poppy Plant, the Production of, International and Wholesale Trade in, and Use of Opium, 1953: see Vol. 6 p. 262.

\section{International Opium Convention, 1925, amended by Protocol 1946}

(Corrected from Vol. 6 p. 260)

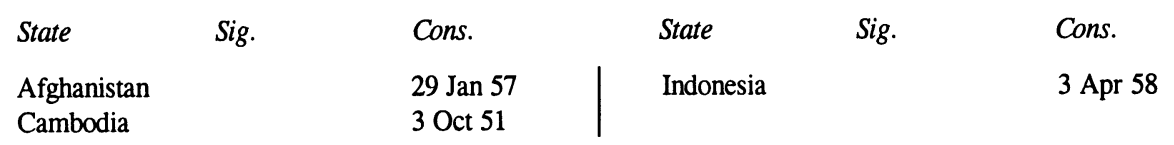

Convention for Limiting the Manufacture and Regulating the Distribution of Narcotic Drugs, 1931, and amended by Protocol, 1946

(Corrected from Vol. 6 p. 261)

$\begin{array}{llllll}\text { State } & \text { Sig. } & \text { Cons. } & \text { State } & \text { Sig. } & \text { Cons. } \\ \text { Cambodia } & & 3 \text { Oct 51 } & \text { Papua } & \\ \text { Indonesia } & & 3 \text { Apr 58 } & \text { New Guinea } & 28 \text { Oct } 80\end{array}$

\section{Single Convention on Narcotic Drugs, 1961}

(Continued from Vol. 6 p. 262)

State Sig. Cons.

Kazakhstan 29 Apr 97 
Protocol amending the Single Convention on Narcotic Drugs, 1961

(Continued from Vol. 6 p. 263)

State Sig." ${ }^{*} \quad$ Cons. ${ }^{* *}$

Kazakhstan 9 Apr 97

Single Convention on Narcotic Drugs, 1961, as Amended by Protocol 1972

(Continued from Vol. 6 p. 263)

\begin{tabular}{|c|c|c|c|c|c|}
\hline State & Sig." & Cons. ${ }^{* *}$ & State & Sig." & Cons. ${ }^{* * *}$ \\
\hline $\begin{array}{l}\text { Kazakhstan } \\
\text { Taiikistan }\end{array}$ & & $\begin{array}{l}29 \text { Apr } 97 \\
26 \text { Mar } 97\end{array}$ & Vietnam & & 4 Nov 97 \\
\hline
\end{tabular}

Convention on Psychotropic Substances, 1971

(Continued from Vol. 6 p. 264)

$\begin{array}{llllll}\text { State } & \text { Sig. } & \text { Cons. } & \text { State } & \text { Sig. } & \text { Cons. } \\ \text { Kazakhstan } & & \text { 29 Apr 97 } & \text { Tajikistan } & & 26 \text { Mar 97 } \\ \text { Laos } & \text { 22 Sep 97 } & \text { Vietnam } & & 4 \text { Nov 97 }\end{array}$

United Nations Convention Against Illicit Traffic in Narcotic Drugs and Psychotropic

Substances, 1988

(Continued from Vol. 6 p. 264)

$\begin{array}{llllll}\text { State } & \text { Sig. } & \text { Cons. } & \text { State } & \text { Sig. } & \text { Cons. } \\ \text { Kazakhstan } & & 29 \text { Apr } 97 & \text { Vietnam } & & 4 \text { Nov } 97 \\ \text { Singapore } & & 23 \text { Oct } 97 & & & \end{array}$

\section{NATIONALITY AND STATELESSNESS}

Convention relating to the Status of Stateless Persons, 1954: see Vol. 6 p. 264.

Optional Protocol to the Vienna Convention on Diplomatic Relations concerning Acquisition of Nationality, 1961: see Vol. 6 p. 265.

Optional Protocol to the Vienna Convention on Consular Relations concerning Acquisition of Nationality, 1963: see Vol. 6 p. 265.

\footnotetext{
* Ratification or accession in respect of Protocol 1972 or participation upon deposit of an instrument of ratification or accession to the Convention of 1961 (art. 19 Protocol).

${ }^{* * *}$ Ratification or accession in respect of the Convention as amended.
} 


\section{NUCLEAR MATERIAL}

Convention on Civil Liability for Nuclear Damage, 1963: see Vol. 6 p. 265.

Convention on the Physical Protection of Nuclear Material, 1980: see Vol. 6 p. 265.

Joint Protocol Relating to the Application of the Vienna Convention (and the Paris Convention on Third Party Liability in the Field of Nuclear Energy), 1980: see Vol. 6 p. 265.

\section{Convention on Early Notification of a Nuclear Accident, 1986}

(Continued from Vol. 6 p. 266)

(Status as at 31 December 1997, provided by IAEA)

$\begin{array}{llllll}\text { State } & \text { Sig. } & \text { Cons. } & \text { State } & \text { Sig. } & \text { Cons. } \\ \text { Myanmar } & & 18 \text { Dec } 97 & \text { Singapore } & & 15 \text { Dec } 97\end{array}$

Convention on Assistance in the Case of a Nuclear Accident or Radiological Emergency, 1986 (Continued from Vol. 6 p. 266)

(Status as at 31 December 1997, provided by IAEA)

State Sig. Cons.

Singapore 15 Dec 97

Convention on Nuclear Safety

Vienna, September 1994

Entry into force: 24 October 1996

(Status as at 31 December 1997, provided by IAEA)

\begin{tabular}{lll|lll} 
State & Sig. & Cons. & State & Sig. & Cons. \\
Bangladesh & 21 Sep 95 & 21 Sep 95 & Kazakhstan & 20 Sep 96 & \\
China & 20 Sep 94 & 9 Apr 96 & Korea (Rep.) & 20 Sep 94 & 19 Sep 95 \\
India & 20 Sep 94 & & Pakistan & 20 Sep 94 & 14 Jun 95 \\
Indonesia & 20 Sep 94 & & Philippines & 14 Oct 94 & \\
Japan & 20 Sep 94 & 12 May 95 & Singapore & & 15 Dec 97
\end{tabular}

Joint Convention on the Safety of Spent Fuel Management and on the Safety of Radioactive Waste Management

Vienna, 5 September 1997

Entry into force: not yet

(Status as at 31 December 1997, provided by IAEA)

$\begin{array}{llllll}\text { State } & \text { Sig. } & \text { Cons. } & \text { State } & \text { Sig. } & \text { Cons. } \\ \text { Indonesia } & \text { 6 Oct 97 } & & \text { Korea (Rep.) } & \text { 29 Sep 97 } & \\ \text { Kazakhstan } & \text { 29 Sep 97 } & & & \end{array}$




\section{Protocol to amend the Convention on Civil Liability for Nuclear Damage \\ Vienna, 12 September 1997 \\ Entry into force: not yet \\ (Status as at 31 December 1997, provided by IAEA)}

State Sig. Cons.

Indonesia $\quad 6$ Oct 97

\section{Convention on Supplementary Compensation for Nuclear Damage \\ Vienna, 12 September 1997 \\ Entry into force: not yet \\ (Status as at 31 December 1997, provided by IAEA)}

State Sig. Cons.

Indonesia $\quad 6$ Oct 97

\section{OUTER SPACE}

Treaty on Principles Governing the Activities of the States in the Exploration and Use of Outer Space, Including the Moon and Other Celestial Bodies, 1967: see Vol. 6 p. 266. Agreement governing the Activities of States on the Moon and other Celestial Bodies, 1979: see Vol. 6 p. 267.

\section{Convention on Registration of Objects launched into Outer Space, 1974}

(Continued from Vol. 6 p. 267)

State Sig. Cons.

Indonesia $\quad 16 \mathrm{Jul} 97$

\section{PRIVILEGES AND IMMUNITIES}

Convention on the Privileges and Immunities of the United Nations, 1946: see Vol. 6 p. 267.

Vienna Convention on Diplomatic Relations, 1961: see Vol. 6 p. 268

Optional Protocol to the Vienna Convention on Diplomatic Relations concerning the Compulsory Settlement of Disputes, 1961: see Vol. 6 p. 269.

Optional Protocol to the Vienna Convention on Consular Relations concerning the Compulsory Settlement of Disputes, 1963: see Vol. 6 p. 269.

Convention on Special Missions, 1969: see Vol. 6 p. 269.

Optional Protocol to the Convention on Special Missions concerning the Compulsory Settlement of Disputes, 1969: see Vol. 6 p. 269. 
Convention on the Privileges and Immunities of the Specialized Agencies, 1947

(Continued from Vol. 6 p. 268)

$\begin{array}{lll}\text { State } & \text { Cons. } & \text { Applicable to } \\ \text { Nepal } & \text { 11 Sep 1996 } & \text { ILO } \\ \text { Uzbekistan } & \text { 18 Feb 97 } & \text { ILO, ICAO, UNESCO, IMF, IBRD, WHO (Annex rev.), UPU, } \\ & & \text { ITU, WMO, IFC, IDA, WIPO, UNIDO }\end{array}$

\section{Vienna Convention on Consular Relations, 1963}

(Continued from Vol. 6 p. 269)

State

Sig. Cons.

Myanmar

2 Jan 97

\section{REFUGEES}

Convention relating to the Status of Refugees, 1951: see Vol. 6 p. 270.

Protocol relating to the Status of Refugees, 1967: see Vol. 6 p. 270.

\section{ROAD TRAFFIC AND TRANSPORT}

Convention on Road Traffic, 1968

(Continued from Vol. 6 p. 270)

State Sig. Cons.

Mongolia 19 Dec 97

Convention on Road Signs and Signals, 1968

(Continued from Vol. 6 p. 270)

State Sig. Cons.

Mongolia 19 Dec 97

SEA

Convention on the Territorial Sea and the Contiguous Zone, 1958: see Vol. 6 p. 271.

Convention on Fishing and Conservation of the Living Resources of the High Seas, 1958: see Vol. 6 p. 271.

Convention on the Continental Shelf, 1958: see Vol. 6 p. 271.

Optional Protocol of Signature concerning the Compulsory Settlement of Disputes, 1958: see Vol. 6 p. 272. 


\section{Convention on the High Seas, 1958}

(Corrected from Vol. 6 p. 271)

$\begin{array}{lll}\text { State } & \text { Sig. } & \text { Cons. } \\ \text { Malaysia } & & 21 \text { Dec } 60\end{array}$

United Nations Convention on the Law of the Sea, 1982

(Continued from Vol. 6 p. 272)

\begin{tabular}{lll|lll} 
State & Sig. & Cons. & State & Sig. & Cons. \\
Pakistan & 10 Dec 82 & 26 Feb 97 & $\begin{array}{l}\text { Papua } \\
\text { New Guinea }\end{array}$ & 10 Dec 82 & 14 Jan 97
\end{tabular}

Agreement relating to the Implementation of Part XI of the United Nations Convention on the Law of the Sea of 10 December 1982, 1994

(Continued from Vol. 6 p. 272)

\begin{tabular}{lll|lll} 
State & Sig. & Cons. & State & Sig. & Cons. \\
Pakistan & 10 Aug 94 & 26 Feb 97 & Papua & & \\
Philippines & 15 Nov 94 & 23 Jul 97 & New Guinea & 10 Dec 82 & 14 Jan 97
\end{tabular}

\section{SEA TRAFFIC AND TRANSPORT}

Convention Regarding the Measurement and Registration of Vessels employed in Inland Navigation, 1956: see Vol. 6 p. 273.

International Convention for the Safety of Life at Sea, 1960: see Vol. 6 p. 273.

Convention on Facilitation of International Maritime Traffic, 1965 (as amended): see Vol. 6 p. 273.

International Convention on Load Lines, 1966: see Vol. 6 p. 274.

Special Trade Passenger Ships Agreement, 1971, see Vol. 6 p. 275.

Protocol on Space Requirements for Special Trade Passenger Ships, 1973: see Vol. 6 p. 275.

Convention on the International Regulations for Preventing Collisions at Sea, 1972 as amended: see Vol. 6 p. 275.

International Convention for Safe Containers, as amended 1972: see Vol. 6 p. 275.

Convention on a Code of Conduct for Liner Conferences, 1974: see Vol. 6 p. 276.

International Convention for the Safety of Life at Sea, 1974, as amended: see Vol. 6 p. 276.

Protocol Relating to the International Convention for the Safety of Life at Sea, 1974 (as amended): see Vol. 6 p. 276

UN Convention on the Carriage of Goods by Sea, 1978: see Vol. 6 p. 276.

International Convention on Tonnage Measurement of Ships, 1969

(Continued from Vol. 6 p. 274)

(Status as included in IMO doc. J/6783, as at 31 December 1997) 


$\begin{array}{lll}\text { State } & \text { Cons. (deposit) } & \text { E.i.f. } \\ \text { Thailand } & 11 \text { Jun } 96 & \text { 11 Sep } 96\end{array}$

Protocol Relating to the International Convention on Load Lines, 1981

(Continued from Vol. 6 p. 274)

(Status as included in IMO doc. J/6783, as at 31 December 1997)

State Cons. (deposit) E.i.f.

Japan 24 Jun 97

\section{SOCIAL MATTERS}

International Convention for the Suppression of the Circulation of and Traffic in Obscene Publications, 1923: see Vol. 6 p. 277.

International Convention for the Suppression of the Traffic in Women and Children, 1921: see Vol. 6 p. 277.

Convention for the Suppression of the Circulation of, and Traffic in, Obscene Publications, 1923, amended by Protocol in 1947: see Vol. 6 p. 277.

International Convention for the Suppression of the Traffic in Women of Full Age, 1933: see Vol. 6 p. 277.

Convention for the Suppression of the Traffic in Women and Children, 1921, amended by Protocol in 1947, see Vol. 6 p. 277.

Convention for the Suppression of the Traffic in Women of Full Age, 1933, amended by Protocol, 1947: see Vol. 6 p. 277.

International Agreement for the Suppression of the White Slave Traffic, 1904, amended by Protocol 1949: see Vol. 6 p. 278.

International Convention for the Suppression of the White Slave Traffic, 1910, amended by Protocol 1949: see Vol. 6 p. 278.

Agreement for the Suppression of the Circulation of Obscene Publications, 1910, amended by Protocol 1949: see Vol. 6 p. 278.

Final Protocol to the Convention for the Suppression of the Traffic in Persons and of the Exploitation of the Prostitution of Others, 1950: see Vol. 6 p. 278.

\section{Convention for the Suppression of the Traffic in Persons and of the Exploitation of the}

Prostitution of Others, 1950

(Continued from Vol. 6 p. 278)

State Sig. Cons.

Kyrgyzstan 5 Sep 97 


\section{TELECOMMUNICATIONS}

Convention on the International Maritime Satellite Organization (INMARSAT), 1976 (as amended): see Vol. 6 p. 280.

Agreement establishing the Asia-Pacific Institute for Broadcasting Development, 1977: see Vol. 6 p. 280.

Amendment to Article 11, Paragraph 2(a), of the Constitution of the Asia-Pacific Telecommunity, 1981: see Vol. 6 p. 279.

\section{Constitution of the Asia-Pacific Telecommunity, 1976}

(Corrected from Vol. 6 p. 279)

$\begin{array}{llllll}\text { State } & \text { Sig. } & \text { Cons. } & \text { State } & \text { Sig. } & \text { Cons. } \\ \text { Indonesia } & & 29 \mathrm{Apr} 85 & \text { Korea (DPR) } & & 22 \text { Feb } 94\end{array}$

Amendments to articles 3(5) and 9(8) of the Constitution of the Asia-Pacific Telecommunity, 1991

(Continued from Vol. 6 p. 279)

$\begin{array}{llllll}\text { State } & \text { Sig. } & \text { Cons. } & \text { State } & \text { Sig. } & \text { Cons. } \\ \text { Malaysia } & & 6 \text { May } 97 & \text { Vietnam } & & 7 \text { Jan } 97\end{array}$

\section{TREATIES}

Vienna Convention on the Law of Treaties Between States and International Organizations or Between International Organizations, 1986: see Vol. 6 p. 280.

\section{Vienna Convention on the Law of Treaties, 1969}

(Continued from Vol. 6 p. 280)

State Sig. Cons.

China $\quad 3$ Sep 97

\section{WEAPONS}

Protocol for the Prohibition of the Use in War of Asphyxiating, Poisonous or other Gases, and of Bacteriological Warfare, 1925: see Vol. 6 p. 281.

Treaty Banning Nuclear Weapon Tests in the Atmosphere, in Outer Space and Under Water, 1963: see Vol. 6 p. 281.

Treaty on the Non-Proliferation of Nuclear Weapons, 1968: see Vol. 6 p. 282.

Treaty on the Prohibition of the Emplacement of Nuclear Weapons and Other Weapons of Mass Destruction on the Sea-Bed and the Ocean Floor and in the Subsoil Thereof, 1971: see Vol. 6 p. 282. 
Convention on the Prohibition of the Development, Production and Stockpiling of Bacteriological (Biological) and Toxin Weapons and on Their Destruction, 1972: see Vol. 6 p. 282.

Convention on the Prohibition of Military or any other Hostile Use of Environmental Modification Techniques, 1976: see Vol. 6 p. 283.

Convention on Prohibitions or Restrictions on the Use of Certain Conventional Weapons which may be Deemed Excessively Injurious or to have Indiscriminate Effects, and Protocols, 1980

(Continued from Vol. 6 p. 283)

$\begin{array}{llllll}\text { State } & \text { Sig. } & \text { Cons. } & \text { State } & \text { Sig. } & \text { Cons. } \\ \text { Cambodia } & & 25 \text { Mar } 97 & \text { Uzbekistan } & & 29 \text { Sep 97 }\end{array}$

Convention on the Prohibition of the Development, Production, Stockpiling and Use of Chemical Weapons and on Their Destruction, 1993

(Continued from Vol. 6 p. 283)

\begin{tabular}{lll|lll} 
State & Sig. & Cons. & State & Sig. & Cons. \\
Bangladesh & 14 Jan 93 & 25 Apr 97 & Korea (Rep.) & 14 Jan 93 & 28 Apr 97 \\
Bhutan & 24 Apr 97 & & Laos & 13 May 93 & 25 Feb 97 \\
Brunei & 13 Jan 93 & 28 Jul 97 & Nepal & 19 Jan 93 & 18 Nov 97 \\
China & 13 Jan 93 & 25 Apr 97 & Pakistan & 13 Jan 93 & 28 Oct 97 \\
Iran & 13 Jan 93 & 3 Nov 97 & Singapore & 14 Jan 93 & 21 May 97
\end{tabular}

